\title{
Genetic Behavior of Some Rice Genotypes under Normal and High Temperature Stress
}

\author{
Mahmoud M. Gaballah ${ }^{1}$ and Aziz F. Abu El-Ezz ${ }^{1}$
}

\begin{abstract}
Thirteen rice genotypes were grown in the two successive rice seasons 2017 and 2018 to assess the presence of variability for desired traits and estimate genetic parameters and correlations for traits under normal and heat stress conditions. Analysis of variance revealed significant differences due to environments, genotypes and their interaction for all studied characteristics in both seasons. The estimates of genotypic (GCV) and phenotypic (PCV) coefficient of variation were highly significant for all studied traits and generally, the PCV values were higher than GCV values, in both seasons. Leaf rolling and sterility percentage increased under heat stress, while days to heading, plant height, number of tillers and number of panicles / plant, 100-grainweight and grain yield/plant decreased under heat stress in comparison to normal condition. As mean performance Giza 179, Giza 178 and Sakha 101 surpassed other genotypes in grain yield and its important attributes, while WAB56-50/Sakha101-1, WAB56-50/Sakha101-2 and IR65907-206-7-8/Gyehwa71 gave the lowest grain yield in both seasons. Giza178 and WAB56-50/Sakha101-1 recorded the lowest values of geometric mean productivity, stress susceptibility index and yield index which refer to those genotypes highly tolerance to heat stress, while Giza 177 and Sakha 101 gave the highest values to be the most heat susceptible genotypes under study. Highly positive and significant phenotypic correlations were observed between yield index and leaf rolling, sterility percentage, geometric mean productivity and stress susceptibility index, otherwise number of tillers/plant, number of panicles/panicle and panicle weight, as yield attributes had highly significant negative correlation with the yield index. From the results we can conclude that, the genotypes can be scored as heat tolerant, based on days to heading, leaf rolling, tillering productivity and spikelets sterility percentage.
\end{abstract}

Keywords: Heritability, Genetic advance, phenotypic correlation, heat stress, Rice.

\section{INTRODUCTION}

The rising temperatures associated with global warming may have serious direct and indirect

DOI: 10.21608/ASEJAIQJSAE.2019.40780

Rice Research and Training Center (RRTC), Rice Research Department, Field Crops Research Institute, Agricultural Research Center, 33717,

Sakha, Kafr Elsheikh, Egypt.

Corresponding authors emails: mahmoudgab@yahoo.com

and abuelezz76@hotmail.com

Received May 30, 2019, Accepted June 29, 2019 consequences on crop production especially in cereals. In the last century, under industrialization, natural environment deterioration and climate change, heat stress has become an increasingly important factor affecting crop growth. Moreover, different global circulation models predict that greenhouse gases will gradually increase world's average ambient temperature. According to a report of the Intergovernmental Panel on Climatic Change (IPCC 2007), global mean temperature will rise $0.3{ }^{\circ} \mathrm{C}$ per decade (Jones et al. 1999) reaching to approximately 1 and $3{ }^{\circ} \mathrm{C}$ above the present value by years 2025 and 2100, respectively, and leading to global warming. Raising temperatures leads to altered geographical distribution and growing season of agricultural crops by allowing the threshold temperature for the start of the season and crop maturity to reach earlier. In addition, climate is expected to be more variable with frequent episodes of stressful temperatures during crop-growing season. As a result, the crop production may be severely affected by an increase in mean global temperature. The yield reduction is a result of heat stress alert in the morphological, physiological, biochemical and molecular changes (Wang et al. 2003). Morphologically, Heat stress decreases of the duration of developmental phases leading to fewer and smaller organs, lower light perception due to a reduced life cycle (Stone 2001; Wang et al. 2003; Han et al. 2009 and Schwarz, et al. 2010). Physiological processes are also affected, such as photosynthetic rate, respiration and the partitioning of assimilates to different organs within the plant, where carbon assimilation is one of the major important factors for cereal yields losses (Stone 2001; Wahid et al. 2007).

Rice is a staple food for more than half the world's population. It is grown worldwide over an area of 159 million hectares with an annual production of 740 million tons. It is cultivated in 114 of the 193 countries of the world (FAOSTAT, 2016). Abiotic stress such as extreme temperatures frequently limits the growth and productivity of the major crop species including cereals. 
As an important cereal crop, rice productivity might decrease globally by about $3.2 \%$ per each degreeCelsius increase in global mean temperature (Zhao et al. 2017). The point of temperature at which the performance of a crop declines is heat stress threshold. As the rice crop is concerned, the optimum temperature is $33^{\circ} \mathrm{C}$ (Jagadish et al. 2007). Therefore, the exposure to high temperature over $35^{\circ} \mathrm{C}$ induce spikelets sterility and unfilled grain formation (Satake and Yoshida, 1978; Ohe et al. 2007; Jagadish et al. 2007). High temperature affects rice plant growth throughout its ontogeny, though heat-threshold level varies considerably at different developmental stages. For instance, during seed germination, high temperature may slow down or totally inhibit germination, depending on plant species and the intensity of the stress (Yoshida, 1981). Physiologically, high temperature over $35{ }^{\circ} \mathrm{C}$ may adversely affect photosynthesis, respiration, water relations, membrane stability and primary and secondary metabolites (Yoshida et al. 1981; Crafts-Brandner and Law 2000; Griffin et al. 2004). Furthermore, throughout plant ontogeny, enhanced expression of a variety of heat shock proteins, other stress-related proteins, and production of reactive oxygen species (ROS) constitute major plant responses to high temperature (Wahid et al. 2007). The response to heat stress depends on plant species and genotypes (Rampino et al. 2006), so very important to identify the tolerant genotypes based on its physiological and morphological performance under heat stress. The phenotypic correlation among some heat morphological traits and their contribution to grain yield trait under heat stress were directly or indirectly expected in rice. The thousand grain weight and spikelet fertility showed positive and significant association with yield per plant under heat stress at the genotypic level. The heritability was found to be highest for number of grains per panicle, days to maturity, plant height and paddy yield while, lowest for number of tillers per plant. Paddy yield had strong genetic correlation with number of grains per panicle, days to maturity and 1000-grain weight (Akhtar et al 2011). The objectives of the present study were to understand the effect of high temperatures stress on yield and related parameter of rice, to assess genetic variability of rice genotypes, estimate the phenotypic correlation based on agro-morphological traits and applicability of several stress indices under high heat stress condition.

\section{MATERIALS AND METHODS}

In the present investigation, thirteen rice genotypes (Table 1) were used. The experiments were conducted under normal condition (Sakha Agricultural Research Station) and high heat stress condition (Elkharga Agricultural Research station) in 2017 and 2018 rice successive seasons. The nursery was sown on $25^{\text {th }}$ and $15^{\text {th }}$ of April in 2017 and 2018 seasons, respectively, and transplanted to the field after 30 days in both locations. Individual seedlings of each variety were transplanted to 5 rows $20 \mathrm{~cm}$ apart between rows, with the distance of $20 \mathrm{~cm}$ between the hills within a row. The experiment was designed using a randomized complete block design with three replications. The average of temperature and humidity degrees in Sakha and Kharga research stations in 2017 and 2018 years were illustrated in Figure 1. The soil properties in the two locations are shown in Table 2 as well. Phosphorus and potassium were applied in full dose during land preparation in the permanent field and Nitrogen fertilizer was applied in three splits as top dressing. Insects and weeds were controlled periodically using pesticides and herbicides, respectively as required. Analysis of variance was conducted for all the traits using combining analysis according to Steel et al. 1997.

Heritability in broad sense and genetic advance was estimated for all traits using the formula given by Falconer and Mackey (1996).

$$
\mathrm{h}^{2}=\sigma^{2} \mathrm{~g} / \sigma^{2} \mathrm{ph}
$$

Where, $h^{2}$ : Heritability; $\sigma^{2}$ g: genotypic variance and $\sigma^{2} \mathrm{ph}$ : phenotypic variance. Genotypic $\left(\sigma^{2} \mathrm{~g}\right)$ and phenotypic variance $\left(\sigma^{2} \mathrm{ph}\right)$ were obtained from the analysis of variance table according to Comstock and Robinson 1952, as follows

$\sigma^{2} \mathrm{~g}=\left(\mathrm{MS}_{1}-\mathrm{MS}_{2}\right) /(\mathrm{r} \times \mathrm{s}) \quad \sigma^{2} \mathrm{ph}=\mathrm{MS}_{1} /(\mathrm{r} \times \mathrm{s})$

Where,

r: replication, s: season $\mathrm{MS}_{1}$ : Mean squares for cultivar, $\mathrm{MS}_{2}$ : Mean squares for cultivar $\times$ season.

Genetic advance was computed following Poehlman and Sleper 1995. The phenotypic correlation coefficient estimates were carried out using the formula given by Kown and Torrie 1964). Grain yield (t/ha) was considered as the resultant variables and others as causal variables. Statistical significance of phenotypic environmental correlation was determined by using t-test as described by Steel et al. 1997. The genetic analysis and phenotypic correlation and genetic variability were performed on combined data across seasons. The characters measured included days to heading (DTH) (day), leaf rolling(LR), flag leaf angle (FLA) $\left(^{\circ}\right.$ ), plant height $(\mathrm{PH})(\mathrm{cm})$, panicles length $(\mathrm{PL})(\mathrm{cm})$, number of tillers/plant(NT), number of panicles/plant (NP), panicle weight $(\mathrm{PW})(\mathrm{g})$, 100-grain weight $(\mathrm{HGW})$, sterility percentage and grain yield $(\mathrm{GY})(\mathrm{g} /$ plant $)$ as well as three stress indices as follow. 
Table 1. The pedigree and characteristics of rice genotypes used in the study.

\begin{tabular}{|c|c|c|c|}
\hline & Genotype & Pedigree & $\begin{array}{l}\text { Salience and feature } \\
\end{array}$ \\
\hline 1 & Giza177 & Giza171 / Yu mji No.1 // piNo.4 & $\begin{array}{l}\text { Japonica type - sensitive to heat - short stature- early } \\
\text { duration- resistance to blast }\end{array}$ \\
\hline 2 & Giza178 & Giza175/ Milyang 49 & $\begin{array}{l}\text { Indica/Japonic type, medium maturing, semi-dwarf, } \\
\text { resistant to blast, medium grain, tolerant to } \\
\text { heat and high yield }\end{array}$ \\
\hline 3 & Giza179 & GZ6296 / GZ1368 & $\begin{array}{l}\text { Japonica type - moderate to heat - short stature- early } \\
\text { duration- resistant to blast }\end{array}$ \\
\hline 4 & Sakha101 & Giza 176/ Milyange & $\begin{array}{l}\text { Japonica type - sensitive to heat - short stature- long } \\
\text { duration- sensitive to blast }\end{array}$ \\
\hline 5 & Sakha102 & GZ4096-7-1/GZ4120-2-5-2 (Giza 177) & $\begin{array}{l}\text { Japonica type - sensitive to drought - short stature- } \\
\text { early duration- resistance to blast }\end{array}$ \\
\hline 6 & Sakha103 & Giza177/Suweon349 & $\begin{array}{l}\text { Japonica type - sensitive to heat - short stature- early } \\
\text { duration- resistance to blast }\end{array}$ \\
\hline 7 & Sakha104 & GZ4096-8-1/GZ4100-9-1 & $\begin{array}{l}\text { Japonica type - sensitive to heat - long stature- } \\
\text { moderate duration- sensitive to blast }\end{array}$ \\
\hline 8 & Sakha105 & GZ5581-46-3/GZ4316-7-1-1 & $\begin{array}{l}\text { Japonica type - sensitive to heat - short stature- early } \\
\text { duration- resistant to blast }\end{array}$ \\
\hline 9 & Sakha106 & Giza176 / Milyang79 & $\begin{array}{l}\text { Japonica type - sensitive to heat - long stature- early } \\
\text { duration- resistant to blast }\end{array}$ \\
\hline 10 & Sakha107 & Giza 177 /BLI & $\begin{array}{l}\text { Japonica type - tolerant to heat - short stature- early } \\
\text { duration- resistant to blast }\end{array}$ \\
\hline 11 & - & WAB 56-50/ Sakha101-1 & $\begin{array}{l}\text { Japonica type - tolerant to heat - short stature- early } \\
\text { duration- tolerant to blast }\end{array}$ \\
\hline 12 & - & WAB 56-50/ Sakha101-2 & $\begin{array}{l}\text { Japonica type - tolerant to heat - short stature- early } \\
\text { duration- tolerant to blast }\end{array}$ \\
\hline 13 & - & IR 65907-206-7-8/ Gyehwa 71 & $\begin{array}{l}\text { Japonica type - tolerant to heat - short stature- early } \\
\text { duration- tolerant to blast }\end{array}$ \\
\hline
\end{tabular}

Table 2. Physical and chemical properties of the soil in Sakha and Kharga research stations in 2017 and 2018 years.

\begin{tabular}{lcccc}
\hline \multirow{2}{*}{ Soil physical and chemical properties } & \multicolumn{2}{c}{ Sakha, Kafr El-Sheikh } & \multicolumn{2}{c}{ Kharga, El-Wady El-Gaded } \\
\cline { 2 - 5 } & $\mathbf{2 0 1 7}$ & $\mathbf{2 0 1 8}$ & $\mathbf{2 0 1 7}$ & $\mathbf{2 0 1 8}$ \\
\hline Clay\% & 55 & 55 & 3.56 & 3.56 \\
Silt \% & 32.4 & 32.4 & 1.77 & 1.77 \\
Sand \% & 12.6 & 12.6 & 94.65 & 94.65 \\
Texture & Clayey & Clayey & Loamy Sandy & Loamy Sandy \\
Organic Matter & 1.39 & 1.39 & 1.14 & 1.29 \\
pH & 8.1 & 8.2 & 8.8 & 8.7 \\
Ec (Ds/m) & 3.30 & 3.33 & 1.56 & 1.55 \\
Total N(ppm) & 512 & 518 & 235 & 252 \\
Available P(ppm) & 15.09 & 16.03 & 13.6 & 13.9 \\
Co3 & - & - & 2 & 2 \\
Hco3 & 5.55 & 5.56 & 1.5 & 1.5 \\
Mg & 4.3 & 5 & 0.48 & 0.48 \\
Na & 1.88 & 1.69 & 0.035 & 0.032 \\
K & 16 & 16 & 0.23 & 0.27 \\
Fe & 4.55 & 4.55 & 53.1 & 51.6 \\
Mn & 3.1 & 3.5 & 1.3 & 1.4 \\
\hline
\end{tabular}



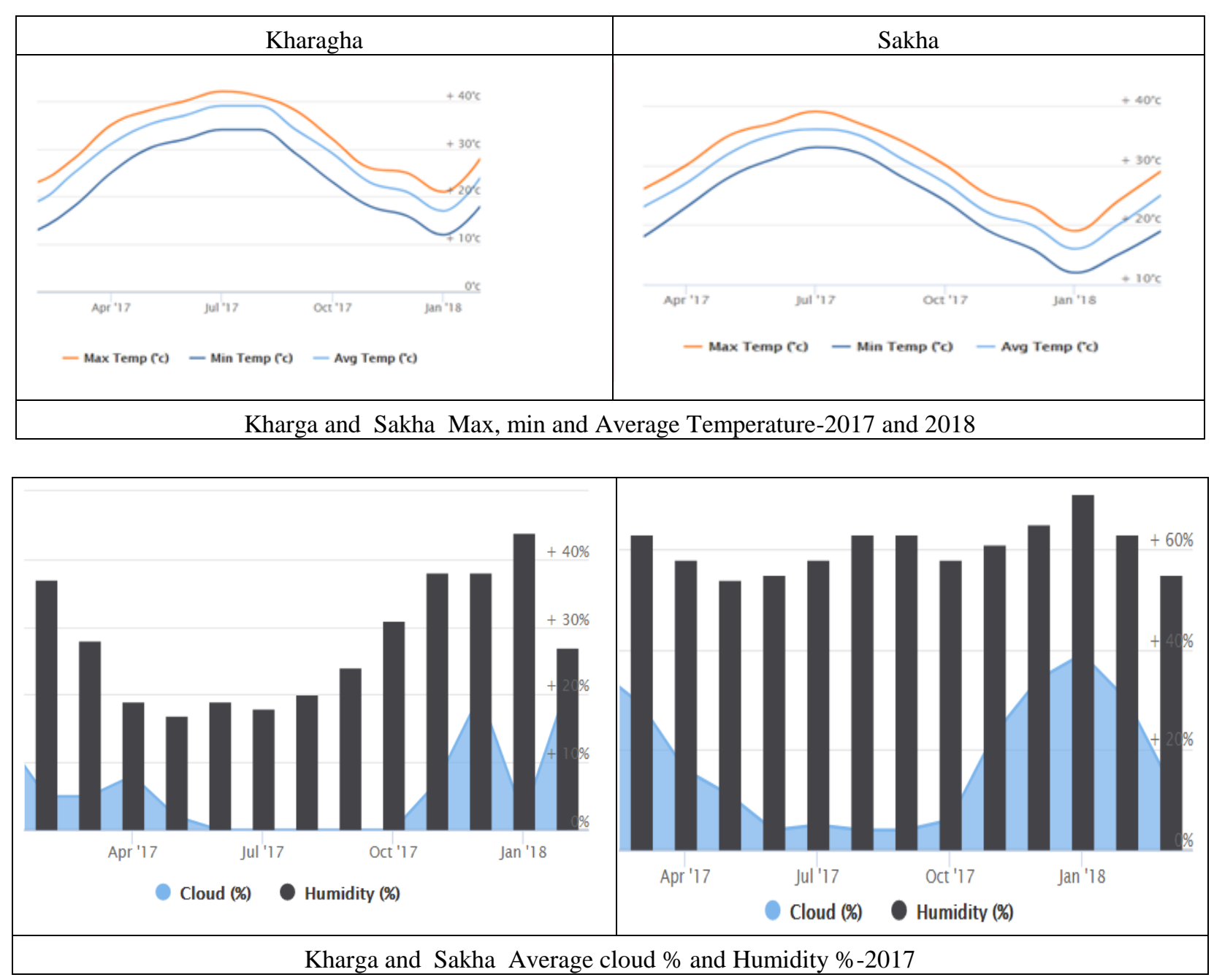

Figure 1. Illustrate the average of temperature and humidity degrees in Sakha and Kharga research stations in 2017 and 2018 years

1.Geometric mean productivity, GMP $=\sqrt{ }(\mathrm{Ys})(\mathrm{Yp})$

(Ramirez and Kelly, 1998)

$\begin{gathered}\text { 2. Stress susceptibility index (SSI) } \\ (\text { Fischer and Maurer, 1978) }\end{gathered}=\frac{1-\mathrm{Ys}_{\mathrm{s}} / \mathrm{Yp}}{1-\mathrm{Y}_{\mathrm{s}}^{-} / \mathrm{Y}_{\mathrm{p}}^{-}}$

3. Yield index $(\mathrm{YI})=\frac{\mathrm{Ys}}{\mathrm{Y}^{-}} \quad$ (Gavuzzi et al. 1997)

Where, Ys denote the mean yield of genotype under stress, Yp the mean yield of genotype under non-stress conditions, $\mathrm{Y}^{-} \mathrm{s}$ is the mean yield of genotype under stress and $Y^{-p} p$ is the mean genotype under normal condition.

\section{RESULTS AND DISCUSSION}

The analysis of variance for studied characteristics is presented in Table 3. Mean squares due to environments were found to be highly significant for all studied characteristics, indicating that; all environments showed significant effects on all traits under study. Additionally, the mean squares due to genotypes were highly significant for all studied traits. These results may comply with that concluded by Porter and Moot 1998; where they found both plant growth and developments are affected by temperature. Also, the significant differences among rice genotypes in Table 3 indicated the presence of genetic variability in the used material and provide a good opportunity for yield improvement. Mean squares due to genotypes $\mathrm{x}$ environments were highly significant for all studied traits, which indicated 
that the tested genotypes varied from one environment to the other and ranked differently from normal to heat stresses conditions. It could be considered that some genotypes surpassed others if the mean squares of genotypes were highly significant than the interaction mean squares of genotypes with environments and therefore we can identify the most superior varieties (genotypes). Table (2) illustrated the soil properties of the two experimental sites in both seasons and showed no significant differences between the two seasons for each location.

Grain yield and other characters exhibited stability across the seasons, since the significance of genotype $\times$ environment interaction was detected and the differences among genotypes were identified (Table 3). This could show that further improvement through selection for all characters studied may be effective. These findings are in agreement with the results of Gaballah 2016.

\section{Performance across environments:}

The mean performances of the studied genotypes over environments, normal and high heat stress under 2017 and 2018 rice growing seasons are presented in Table (4). High temperature stress reduce plant duration via stimulate rice genotypes to early flowering, reduce the flag leaf angle, decrease plant height and panicle length, reduce number of tillers/plant, and number of panicle/plant and produced the lowest panicle weight and 100-grain weight. Moreover, the grain yield/plant was significantly reduced, whereas the lowest values (19.29 \& $19.42 \mathrm{~g} / \mathrm{p})$ under heat stress, in compared to (41.19 \& $41.47 \mathrm{~g} / \mathrm{p})$ under normal condition, in 2017 and 2018 seasons, respectively. The increment of temperature had significant negative effect on the grain productivity, particularly high night temperatures, where a narrow critical range of $2-3^{\circ} \mathrm{C}$ has been shown to result in the grain yield reduction in the tropical and suptropical areas (Nagarajan et al. 2010; Peng et al. 2004).

Table 3. The combined analysis of variance for studied agronomic characteristics.

\begin{tabular}{|c|c|c|c|c|c|c|c|c|c|}
\hline \multirow{2}{*}{ S O V } & \multirow{2}{*}{ df } & \multicolumn{2}{|c|}{ Days to Heading (day) } & \multicolumn{2}{|c|}{ Leaf Rolling } & \multicolumn{2}{|c|}{ Flag Leaf Angle $\left(^{\circ}\right)$} & \multicolumn{2}{|c|}{ Plant Height (cm) } \\
\hline & & 2017 & 2018 & 2017 & 2018 & 2017 & 2018 & 2017 & 2018 \\
\hline Blocks & 2 & $4.66 \mathrm{~ns}$ & $4.72 \mathrm{~ns}$ & $0.01 \mathrm{~ns}$ & $0.01 \mathrm{~ns}$ & $2.14 *$ & $2.17 *$ & $17.23 * *$ & $17.47 * *$ \\
\hline Environments & 1 & $5899.3 * *$ & $5982.20 * *$ & $66.18 * *$ & $67.13 * *$ & $250.20 * *$ & $253.84 * *$ & $15149.71 * *$ & $15363.13 *$ \\
\hline Genotypes & 12 & $205.6 * *$ & $208.46^{* *}$ & $8.51 * *$ & $8.65 * *$ & $1492.64 * *$ & $1513.58 * *$ & $71.57 * *$ & $72.58 * *$ \\
\hline En $x$ gen & 12 & $47.01 * *$ & $47.66^{* *}$ & $2.20 * *$ & $2.24 * *$ & $83.76^{* *}$ & $84.92 * *$ & $113.52 * *$ & $115.19 * *$ \\
\hline Error & 50 & 2.45 & 2.49 & 0.005 & 0.005 & 0.62 & 0.63 & 2.01 & 2.037 \\
\hline \multirow{2}{*}{ SO V } & \multirow{2}{*}{ df } & \multicolumn{2}{|c|}{ Panicles Length (cm) } & \multicolumn{2}{|c|}{ number of tillers/plant } & \multicolumn{2}{|c|}{ Number of Panicles/plant } & \multicolumn{2}{|c|}{ Panicle Weight (g) } \\
\hline & & 2017 & 2018 & 2017 & 2018 & 2017 & 2018 & 2017 & 2018 \\
\hline Blocks & 2 & $0.50 *$ & $0.49 *$ & $0.35 * *$ & $0.35 * *$ & $0.059 \mathrm{~ns}$ & $0.058 \mathrm{~ns}$ & $0.016 * *$ & $0.016 * *$ \\
\hline Environments & 1 & $296.32 * *$ & $300.66 * *$ & $1161.55^{* *}$ & $1177.89 * *$ & $1053.43 * *$ & $1067.96 * *$ & $165.44 * *$ & $167.78 * *$ \\
\hline Genotypes & 12 & $9.75 * *$ & $9.88 * *$ & $11.36^{* *}$ & $11.53 * *$ & $12.93 * *$ & $13.108 * *$ & $0.66 * *$ & $0.68 * *$ \\
\hline En $x$ gen & 12 & $16.05^{* *}$ & $16.28 * *$ & $13.34 * *$ & $13.52 * *$ & $11.60 * *$ & $11.77 * *$ & $0.62 * *$ & $0.62 * *$ \\
\hline Error & 50 & 0.09 & 0.1 & 0.06 & 0.06 & 0.063 & 0.06 & 0.002 & 0.002 \\
\hline
\end{tabular}

(NS) = Not Significant, $(*)=$ Significant at 0.05 and $(* *)=$ Significant at 0.01 level of probability.

Table 3. Cont'd

\begin{tabular}{cccccccc}
\hline \multirow{2}{*}{ S O V } & \multirow{2}{*}{ df } & \multicolumn{2}{c}{$\mathbf{1 0 0 - G r a i n ~ W e i g h t ~}(\mathbf{g})$} & \multicolumn{2}{c}{ Sterility Percentage (\%) } & \multicolumn{2}{c}{ Grain yield/plant (g) } \\
\cline { 3 - 7 } & & $\mathbf{2 0 1 7}$ & $\mathbf{2 0 1 8}$ & $\mathbf{2 0 1 7}$ & $\mathbf{2 0 1 8}$ & $\mathbf{2 0 1 7}$ & $\mathbf{2 0 1 8}$ \\
\hline Blocks & 2 & $0.010^{* *}$ & $0.01^{* *}$ & $0.148 \mathrm{~ns}$ & $0.15 \mathrm{~ns}$ & $1.5028^{* *}$ & $1.52^{* *}$ \\
Environments & 1 & $6.71^{* *}$ & $6.78^{* *}$ & $24424.93^{* *}$ & $24768.37^{* *}$ & $9350.64^{* *}$ & $9480.50^{* *}$ \\
Genotypes & 12 & $0.36^{* *}$ & $0.36^{* *}$ & $504.51^{* *}$ & $511.63^{* *}$ & $130.94^{* *}$ & $132.75^{* *}$ \\
En x gen & 12 & $0.09^{* *}$ & $0.091^{* *}$ & $558.97^{* *}$ & $566.76^{* *}$ & $265.86^{* *}$ & $269.62^{* *}$ \\
Error & 50 & 0.001 & 0.001 & 0.299 & 0.303 & 0.27 & 0.28 \\
& & Geometric Mean & Stress susceptibility index & \multicolumn{2}{c}{ Yield index } \\
S O V & df & $\mathbf{2 0 1 7}$ & $\mathbf{2 0 1 8}$ & $\mathbf{2 0 1 7}$ & $\mathbf{2 0 1 8}$ & $\mathbf{2 0 1 7}$ & $\mathbf{2 0 1 8}$ \\
\hline Blocks & 2 & $0.1777 \mathrm{~ns}$ & $0.4740 \mathrm{~ns}$ & $0.0001 \mathrm{~ns}$ & $0.0017 \mathrm{~ns}$ & $0.0003 \mathrm{~ns}$ & $0.0006 \mathrm{~ns}$ \\
Genotypes & 12 & $51.66^{* *}$ & $58.61^{* *}$ & $1.31^{* *}$ & $1.201^{* *}$ & $0.24 * *$ & $0.24^{* *}$ \\
Error & 24 & 1.8952 & 1.3865 & 0.1110 & 0.0045 & 0.0045 & 0.0052 \\
\hline
\end{tabular}

$(\mathrm{NS})=$ Not Significant, $(*)=$ Significant at 0.05 and $(* *)=$ Significant at 0.01 level of probability. 
Table 4. Mean performances of the agronomic traits under normal and heat stress environments for 2017 and 2018 rice growing seasons.

\begin{tabular}{|c|c|c|c|c|c|c|c|c|c|c|c|c|}
\hline \multirow[t]{2}{*}{ Environment } & \multicolumn{2}{|c|}{$\begin{array}{l}\text { Days to heading } \\
\text { (day) }\end{array}$} & \multicolumn{2}{|c|}{ Leaf rolling } & \multicolumn{2}{|c|}{$\begin{array}{c}\text { Flag leaf angle } \\
\left({ }^{\circ}\right)\end{array}$} & \multicolumn{2}{|c|}{$\begin{array}{l}\text { Plant height } \\
(\mathbf{c m})\end{array}$} & \multicolumn{2}{|c|}{$\begin{array}{c}\text { Panicles length } \\
(\mathrm{cm})\end{array}$} & \multicolumn{2}{|c|}{$\begin{array}{l}\text { Number of } \\
\text { tillers/plant }\end{array}$} \\
\hline & 2017 & 2018 & 2017 & 2018 & 2017 & 2018 & 2017 & 2018 & 2017 & 2018 & 2017 & 2018 \\
\hline Normal & 98.02 & 98.72 & 3.31 & 3.33 & 49.05 & 49.40 & 107.66 & 108.41 & 21.36 & 21.51 & 19.80 & 19.93 \\
\hline Heat stress & 82.62 & 83.20 & 5.15 & 5.19 & 45.47 & 45.79 & 79.79 & 80.34 & 17.47 & 17.59 & 12.08 & 12.16 \\
\hline LSD 0.05 & 0.71 & 0.71 & 0.03 & 0.03 & 0.36 & 0.36 & 0.64 & 0.65 & 0.14 & 0.14 & 0.12 & 0.12 \\
\hline LSD 0.01 & 1.00 & 1.00 & 0.05 & 0.04 & 0.51 & 0.51 & 0.91 & 0.92 & 0.20 & 0.20 & 0.17 & 0.17 \\
\hline \multirow[t]{2}{*}{ Environment } & \multicolumn{2}{|c|}{$\begin{array}{c}\text { Number of } \\
\text { panicles/plant }\end{array}$} & \multicolumn{3}{|c|}{$\begin{array}{c}\text { Panicle weight } \\
\text { (g) }\end{array}$} & \multicolumn{2}{|c|}{$\begin{array}{l}\text { 100-Grain weight } \\
\text { (g) }\end{array}$} & \multicolumn{3}{|c|}{$\begin{array}{c}\text { Sterility percentage } \\
(\%)\end{array}$} & \multicolumn{2}{|c|}{$\begin{array}{c}\text { Grain } \\
\text { yield/plant (g) }\end{array}$} \\
\hline & 2017 & 2018 & & & 2018 & 2017 & 2018 & 2017 & & 18 & 2017 & 2018 \\
\hline Normal & 18.78 & 18.91 & & & 4.08 & 2.83 & 2.85 & 5.81 & & 85 & 41.19 & 41.47 \\
\hline Heat stress & 11.43 & 11.51 & & & 1.14 & 2.24 & 2.26 & 41.20 & & .49 & 19.29 & 19.42 \\
\hline LSD 0.05 & 0.11 & 0.12 & & & 0.02 & 0.02 & 0.02 & 0.25 & & 25 & 0.24 & 0.24 \\
\hline LSD 0.01 & 0.16 & 0.16 & & 3 & 0.03 & 0.03 & 0.03 & 0.35 & & 35 & 0.34 & 0.34 \\
\hline
\end{tabular}

On the other hand, high heat stress has increased leaf rolling and sterility percentage in the two rice growing seasons. The normal condition under Sakha Research Station had given the desirable mean values for all genotypes performance for pervious mentioned traits. These results are compatible with Abdallah 2015. However the optimum temperature for the normal development of rice ranges from 27 to $32{ }^{\circ} \mathrm{C}$ (Yin et al. 1996), and high temperature affects almost all the growth stages of rice, i.e. from emergence to ripening and harvesting. The developmental stage at which the plant is exposed to heat stress determines the severity of the possible damage to the crop (Wahid et al. 2007). In addition, the most stages of development, which are considered to be susceptible to temperature in rice are flowering (anthesis and fertilization) and to a lesser extent the preceding booting stage (Satak and Yoshida 1978; Farrell et al. 2006). IRRI 1976 stated that exposure to $41{ }^{\circ} \mathrm{C}$ for $4 \mathrm{~h}$ at flowering caused irreversible damage and plants became completely sterile. Whereas this high temperature $\left(41^{\circ} \mathrm{C}\right)$ had no effect on spikelet fertility at 1 day before or after flowering (Yoshida et al. 1981).

Regarding days to heading, Sakha 103, Sakha 105 and Sakha 107 headed earlier in comparison to Sakha 101, Giza 178 and Sakha 104 under the two rice seasons, where the earliest variety was Sakha 103; headed after 85.04 days, while Sakha 101 ranked as late flowering variety, it reached 101.88 days to heading (Table. 5). The interaction between environments and genotypes in Table (6) showed highly significance for days to heading trait, where the combination of Giza 107 under heat condition was the earliest heading, after 75.74 day, while the largest number of days to heading (110.18 day) was obtained by IR65907-206-7-
8/Gyehwa71 under normal condition. In the same trend, Nakagawa et al. 2001 found that a temperature increase of $1{ }^{\circ} \mathrm{C}$ shortened the number of days from sowing to heading by $4-5$ days for some genotypes. The leaf rolling trait had highly significant differences among genotypes under both conditions and two rice growing seasons, therefore the genotypes; Giza 178, WAB5650/Sakha101-2 and IR65907-206-7-8/Gyehwa71 exhibited the lowest scores; 2.51, 2.98 and 2.98, respectively of leaf rolling, while Sakha 105, Sakha 106 and Sakha 102 had the highest values; 6.05, 5.57 and 5.58 , respectively. These results seem to indicate that heat susceptibility of some genotypes is associated with high score of leaf rolling (Ayeneha et al. 2002). Data in Table (6) showed highly significant interaction effect on leaf rolling, where Sakha 177 with normal condition had the lowest leaf rolling score (2.99), however Sakha177 under high heat temperature had the highest score (7.08). About 4.19 degrees changed in the leaf rolling score, in response to heat stress to indicate that Giza 177 is more susceptible to heat stress, when compared to IR65907-206-7-8/Gyehwa71, which in more stable genotype, regarding to leaf rolling. With regard to flag leaf angle, which is important functional factor for photosynthesis, assimilation and transpiration along the experimental plant life, recorded the greatest values with significant differences by the varieties. The genotypes; Giza179, IR65907-206-7-8/Gyehwa71 and Giza 178 resulted the narrowest angle, on the other hand the most wide flag leaf angle was observed in genotypes Sakha 101, WAB56-50/Sakha101 and Sakha 102 as shown in Table (5). The combination of IR65907-206-78/Gyehwa71 and normal condition had the narrowest flag leaf angle $\left(17.17^{\circ}\right)$, on contrary; WAB5650/Sakha101-2 gave the widest angle $\left(63.73^{\circ}\right)$ under high temperature condition (Table 6). 
Table 5. Mean performances of genotypes agronomic traits for 2017 and 2018 rice growing seasons.

\begin{tabular}{|c|c|c|c|c|c|c|c|c|c|c|c|c|}
\hline \multirow[t]{2}{*}{ Genotypes } & \multicolumn{2}{|c|}{$\begin{array}{c}\text { Days to } \\
\text { Heading (day) } \\
\end{array}$} & \multicolumn{2}{|c|}{ Leaf Rolling } & \multicolumn{2}{|c|}{ Leaf Angle ( ${ }^{\circ}$ ) } & \multicolumn{2}{|c|}{ Plant Height $(\mathrm{cm})$} & \multicolumn{2}{|c|}{$\begin{array}{c}\text { Panicles Length } \\
(\mathrm{cm})\end{array}$} & \multicolumn{2}{|c|}{$\begin{array}{c}\text { number of } \\
\text { tillers/plant }\end{array}$} \\
\hline & 2017 & 2018 & 2017 & 2018 & 2017 & 2018 & 2017 & 2018 & 2017 & 2018 & 2017 & 2018 \\
\hline Giza 177 & 88.08 & 88.70 & 5.01 & 5.05 & 49.83 & 50.18 & 91.61 & 92.25 & 18.17 & 18.30 & 13.84 & 13.94 \\
\hline Giza 178 & 98.65 & 99.34 & 2.51 & 2.53 & 21.64 & 21.80 & 95.63 & 96.31 & 21.19 & 21.34 & 17.11 & 17.23 \\
\hline Giza179 & 87.58 & 88.19 & 3.01 & 3.03 & 18.12 & 18.25 & 90.85 & 91.49 & 18.78 & 18.91 & 16.25 & 16.36 \\
\hline Sakha 101 & 101.17 & 101.88 & 4.03 & 4.06 & 60.90 & 61.33 & 92.51 & 93.16 & 20.34 & 20.48 & 16.28 & 16.39 \\
\hline Sakha 102 & 87.55 & 88.16 & 5.54 & 5.58 & 58.41 & 58.82 & 100.03 & 100.73 & 20.94 & 21.09 & 16.35 & 16.46 \\
\hline Sakha 103 & 85.04 & 85.63 & 5.49 & 5.52 & 55.69 & 56.07 & 94.60 & 95.26 & 18.79 & 18.92 & 13.99 & 14.09 \\
\hline Sakha 104 & 98.62 & 99.31 & 4.02 & 4.04 & 54.06 & 54.44 & 100.02 & 100.72 & 19.08 & 19.21 & 15.90 & 16.01 \\
\hline Sakha 105 & 85.62 & 86.22 & 6.00 & 6.05 & 55.35 & 55.74 & 90.13 & 90.76 & 20.53 & 20.67 & 13.86 & 13.95 \\
\hline Sakha 106 & 86.54 & 87.15 & 5.54 & 5.57 & 53.84 & 54.22 & 95.39 & 96.06 & 19.83 & 19.97 & 15.05 & 15.15 \\
\hline Sakha 107 & 86.34 & 86.95 & 4.47 & 4.50 & 49.62 & 49.96 & 94.97 & 95.64 & 17.46 & 17.59 & 18.30 & 18.43 \\
\hline $\begin{array}{l}\text { WAB 56- } \\
\text { 50/Sakha101-1 }\end{array}$ & 91.30 & 91.94 & 3.48 & 3.50 & 58.55 & 58.96 & 89.31 & 89.93 & 18.81 & 18.94 & 16.87 & 16.99 \\
\hline $\begin{array}{l}\text { WAB 56- } \\
\text { 50/Sakha101-2 }\end{array}$ & 98.21 & 98.90 & 2.98 & 3.00 & 57.56 & 57.96 & 91.74 & 92.38 & 20.84 & 20.98 & 16.87 & 16.99 \\
\hline $\begin{array}{l}\text { IR 65907-206-7- } \\
\text { 8/ Gyehwa71 }\end{array}$ & 92.47 & 93.12 & 2.98 & 3.00 & 20.84 & 20.99 & 91.59 & 92.24 & 17.66 & 17.79 & 16.52 & 16.64 \\
\hline LSD 0.05 & 1.82 & 1.83 & 0.08 & 0.09 & 0.92 & 0.92 & 1.64 & 1.66 & 0.36 & 0.37 & 0.30 & 0.30 \\
\hline LSD 0.01 & 2.57 & 2.59 & 0.12 & 0.12 & 1.29 & 1.30 & 2.33 & 2.34 & 0.52 & 0.52 & 0.42 & 0.42 \\
\hline
\end{tabular}

Table 5. Cont'd.

\begin{tabular}{|c|c|c|c|c|c|c|c|c|c|c|}
\hline \multirow[t]{2}{*}{ Genotype } & \multicolumn{2}{|c|}{$\begin{array}{c}\text { Number of } \\
\text { Panicles/plant }\end{array}$} & \multicolumn{2}{|c|}{$\begin{array}{l}\text { Panicle Weight } \\
\text { (g) }\end{array}$} & \multicolumn{2}{|c|}{$\begin{array}{l}\text { 100-Grain Weight } \\
\text { (g) }\end{array}$} & \multicolumn{2}{|c|}{$\begin{array}{c}\text { Sterility Percentage } \\
(\%)\end{array}$} & \multicolumn{2}{|c|}{$\begin{array}{c}\text { Grain yield/plant } \\
(\mathrm{g})\end{array}$} \\
\hline & 2017 & 2018 & 2017 & 2018 & 2017 & 2017 & 2018 & 2017 & 2018 & 2017 \\
\hline Giza 177 & 13.34 & 13.43 & 2.57 & 2.59 & 2.55 & 2.57 & 28.19 & 28.38 & 27.13 & 27.32 \\
\hline Giza 178 & 16.47 & 16.58 & 3.12 & 3.14 & 2.24 & 2.25 & 14.55 & 14.66 & 36.44 & 36.69 \\
\hline Giza179 & 16.30 & 16.40 & 2.48 & 2.50 & 2.45 & 2.47 & 22.45 & 22.61 & 38.76 & 39.03 \\
\hline Sakha 101 & 13.49 & 13.59 & 2.47 & 2.49 & 2.90 & 2.91 & 23.46 & 23.62 & 34.73 & 34.97 \\
\hline Sakha 102 & 15.25 & 15.35 & 2.24 & 2.25 & 2.57 & 2.59 & 37.53 & 37.80 & 27.66 & 27.86 \\
\hline Sakha 103 & 13.49 & 13.58 & 2.44 & 2.45 & 2.14 & 2.15 & 39.18 & 39.46 & 27.36 & 27.55 \\
\hline Sakha 104 & 14.24 & 14.34 & 2.70 & 2.72 & 2.89 & 2.90 & 17.99 & 18.12 & 33.06 & 33.29 \\
\hline Sakha 105 & 13.34 & 13.43 & 2.28 & 2.29 & 2.71 & 2.73 & 35.15 & 35.40 & 29.13 & 29.34 \\
\hline Sakha 106 & 14.59 & 14.69 & 2.23 & 2.24 & 2.53 & 2.55 & 25.54 & 25.72 & 29.89 & 30.10 \\
\hline Sakha 107 & 17.76 & 17.89 & 2.69 & 2.71 & 2.47 & 2.48 & 19.25 & 19.39 & 33.94 & 34.18 \\
\hline $\begin{array}{l}\text { WAB 56-50/ } \\
\text { Sakha101-1 }\end{array}$ & 16.31 & 16.42 & 2.33 & 2.34 & 2.76 & 2.78 & 15.78 & 15.89 & 24.35 & 24.52 \\
\hline $\begin{array}{l}\text { WAB 56- } \\
\text { 50/Sakha101-2 }\end{array}$ & 15.52 & 15.63 & 3.29 & 3.32 & 2.19 & 2.21 & 14.71 & 14.81 & 25.48 & 25.65 \\
\hline $\begin{array}{l}\text { IR 65907-206-7- } \\
\text { 8/ Gyehwa 71 }\end{array}$ & 16.27 & 16.39 & 2.85 & 2.87 & 2.62 & 2.64 & 11.76 & 11.85 & 25.17 & 25.35 \\
\hline LSD 0.05 & 0.29 & 0.29 & 0.05 & 0.05 & 0.05 & 0.05 & 0.63 & 0.64 & 0.61 & 0.61 \\
\hline LSD 0.01 & 0.41 & 0.42 & 0.07 & 0.07 & 0.06 & 0.07 & 0.90 & 0.90 & 0.86 & 0.87 \\
\hline
\end{tabular}


The data in Table (5) illustrated highly significant differences between genotypes in plant height, whereas the genotypes; WAB56-50/Sakha101-1, Sakha 105 and Giza179 had the highest mean values, while the lowest mean values observed from Sakha 102, Sakha 104 and Giza 178. As interaction response, IR65907-206-78/Gyehwa71 had the highest mean value $114.52 \mathrm{~cm}$ when grown under normal condition, however the shortest plants $(69.31 \mathrm{~cm})$ was recorded by the same genotype followed by Giza $177(73.75 \mathrm{~cm})$ under high temperature location. The data showed different response for different genotypes under heat stress condition, where the plant height of line IR65907-2067-8/Gyehwa71 decreased from $114.52 \mathrm{~cm}$ to $69.31 \mathrm{~cm}$, to show high sensitivity to heat stress. These findings are in close agreement with those reported by Guan et al. 2010 and Gaballah 2016, where rice genotypes response was assessed by plant height reduction after stress conditions.

Concerning panicle length, Giza 178, Sakha102 and WAB56-50/Sakha101-2 gave the highest mean values, while the lowest values were obtained from Sakha107, IR65907-206-7-8/Gyehwa71 and Giza 177. The combination of genotype; WAB56-50/Sakha101-2 with normal condition gave the highest value $(24.90 \mathrm{~cm})$, otherwise Sakha 103 under high heat stress produced the lowest value $(13.06 \mathrm{~cm})$ of panicle length. Additionally, the number of tillers/plant showed highly significance differences among genotypes, whereas the genotypes Sakha 107, Giza 178 and WAB 56-50/Sakha101 had the highest mean values. In contrast, the lowest mean values were obtained by Giza 177, Sakha 105 and Sakha 103 in both seasons (Table 5). Regarding to the interaction effect between genotypes and environment, the highest mean value of number of tillers was obtained from Sakha102 with normal condition in Sakha location, but the lowest value was gained from Sakha 103 under high heat stress condition in Kharga location (Table 6). With respect to number of panicles/plant, the highest mean values were obtained from Sakha 107, Giza 178 and WAB 56-50/ Sakha101-1, whereas the lowest mean values conformed with Sakha 105, Giza 177 and Sakha 103 in both seasons as shown in Table 5. The interaction between Sakha 107 under normal condition had the maximum values of number of panicle/plant 20.17 while the minimum values were obtained from rice genotype Sakha 103 (7.07) under high heat stress condition (Table 6). The decrement of panicle length and tillering capacity under heat stress generally and for some genotypes particularly, may be due almost $50 \%$ slower in the net photosynthetic rate, of some genotypes at heat stress than normal condition (Andrew et al. 2016).
In Table 5, the panicle weight trait illustrated highly significant differences among genotypes, since rice genotypes; WAB56-50/Sakha101-2, Giza 178 and IR65907-206-7-8/Gyehwa71 gave the heaviest panicle, the lightest panicle was obtained from genotypes; Sakha 106, Sakha 102 and Sakha 105. The combination of Giza178 under normal condition produced the heaviest panicle (4.88 g), otherwise Sakha 106 under heat stress gave lightest value $0.55 \mathrm{~g}$ (Table 6). Concerning 100Grain weight, the highest mean values were found in Sakha101, Sakha 104 and WAB 56-50/Sakha101-1, while Sakha 103, WAB56-50/Sakha101-2 and Giza 178 gave the lightest mean values, as shown in Table (5). The interaction effect in Table (6) illustrated that WAB 56-50/Sakha101-2 had the heaviest 100-grain weight (3.25 g) under normal condition; however the lowest mean value $(1.76 \mathrm{~g})$ was obtained by Sakha 103 under heat stress (Table 6). For sterility percentage, the highest mean values were found in Sakha 103, Sakha 102 Sakha 105 , but the lowest values were obtained by IR65907-206-7-8/Gyehwa71, Giza 178 and WAB5650/Sakha101-2, as shown in Table (5). These data are in agreement with those obtained by Satak and Yoshida 1978; Matsui et al. 2001; Nakagawa et al. 2002; Prasad et al. 2006, where they found genotypic variation in spikelet sterility at high temperature, that can be defined by different varietal temperature thresholds. The interaction between rice cultivar Sakha 107 and normal condition recorded lowest mean value (4.49\%), while Sakha 103 under heat stress recorded the highest percentage of sterility $(74.12 \%)$ (Table 6). Data in Table (5) illustrated the grain yield/plant was significantly affected by rice genotypes, where Giza179, Giza 178 and Sakha 101 achieved the highest mean values, but the lowest values of grain yield per plant were obtained from WAB56-50/Sakha101-1, IR65907206-7-8/Gyehwa71 and WAB56-50/Sakha101-2 in both seasons. Giza 179 performed very well with normal condition, giving the maximum grain yield; $51.72 \mathrm{~g}$ per plant, whereas the lowest mean values $(10.91 \mathrm{~g} / \mathrm{p})$ was observed in Giza 177 under heat stress condition, as shown in Table (6). In general, exposure to heat stress causes grain yield reduction (Prasad et al. 2006), however the plants respond based on the genotype (Rampino et al. 2006) and daily maximum temperature (Nakagawa et al. 2002). Hence the heat threshold is changing from genotype to another based on the thermotolerance ability of each genotype.

Regarding the geometric mean productivity (GM), there were highly significant differences between rice genotypes in both seasons, the genotype show highly ranking tolerance were Giza 178, WAB56- 
50/Sakha101-1 and Sakha 107, while the sensitive genotypes were Giza 177, Sakha103 and Sakha104 for high heat stress in the both seasons. According to stress susceptibility index (SSI), Giza 178, WAB5650/Sakha101-1, Sakha 107 and Sakha 104 ranked to high stress tolerance, while sensitive genotypes were Sakha 101 and Sakha 106 in the two seasons. The yield index (YI) showed highly significance as affected by genotypes, where Giza 178, WAB56-50/Sakha101-1,
WAB56-50/Sakha101-2 and Sakha 107 were specified as highly tolerant for heat stress in both seasons, nevertheless Shaka101, Sakha106 and Sakha105 seemed the most sensitive varieties for high heat stress in both seasons. These results are in harmony with the previous findings concerning growth traits and yield and its attributes, All showed more stability under stress in comparison to normal condition. That also complies with Prasanth et al. 2012; Khan and Dhurve 2016.

Table 6. The interaction between genotypes and environments over average 2017 and 2018 rice growing seasons.

\begin{tabular}{|c|c|c|c|c|c|c|c|c|c|c|c|c|}
\hline \multirow[t]{2}{*}{ Genotype } & \multicolumn{2}{|c|}{$\begin{array}{c}\text { Days to } \\
\text { heading(day) }\end{array}$} & \multicolumn{2}{|c|}{ Leaf rolling } & \multicolumn{2}{|c|}{$\begin{array}{c}\text { Flag leaf } \\
\text { angle }\left({ }^{\circ}\right)\end{array}$} & \multicolumn{2}{|c|}{$\begin{array}{c}\text { Plant height } \\
(\mathrm{cm})\end{array}$} & \multicolumn{2}{|c|}{$\begin{array}{c}\text { Panicles length } \\
(\mathrm{cm})\end{array}$} & \multicolumn{2}{|c|}{$\begin{array}{l}\text { Number of } \\
\text { tiller/plant }\end{array}$} \\
\hline & $\mathbf{N}$ & $\mathbf{H}$ & $\mathbf{N}$ & $\mathbf{H}$ & $\mathbf{N}$ & H & $\mathbf{N}$ & $\mathbf{H}$ & $\mathbf{N}$ & $\mathbf{H}$ & $\mathbf{N}$ & $\mathbf{H}$ \\
\hline Giza 177 & 95.97 & 80.82 & 2.99 & 7.08 & 54.55 & 45.46 & 110.12 & 73.75 & 21.02 & 15.46 & 18.69 & 9.09 \\
\hline Giza 178 & 107.08 & 90.92 & 2.01 & 3.03 & 20.20 & 23.24 & 106.07 & 85.87 & 24.85 & 17.68 & 20.20 & 14.14 \\
\hline Giza179 & 92.94 & 82.84 & 3.00 & 3.03 & 17.17 & 19.20 & 98.50 & 83.85 & 20.51 & 17.17 & 17.68 & 14.94 \\
\hline Sakha 101 & 110.18 & 85.87 & 3.03 & 5.05 & 65.66 & 56.57 & 99.81 & 85.87 & 22.43 & 18.39 & 22.63 & 10.05 \\
\hline Sakha 102 & 94.93 & 80.79 & 5.05 & 6.06 & 65.72 & 51.50 & 111.89 & 88.87 & 22.22 & 19.82 & 21.82 & 11.00 \\
\hline Sakha 103 & 93.92 & 76.75 & 4.04 & 6.97 & 63.29 & 48.47 & 110.08 & 79.78 & 24.64 & 13.06 & 20.00 & 8.08 \\
\hline Sakha 104 & 105.09 & 86.85 & 3.03 & 5.03 & 54.97 & 53.53 & 113.11 & 87.63 & 19.79 & 18.50 & 19.79 & 12.12 \\
\hline Sakha 105 & 96.10 & 75.74 & 5.05 & 7.00 & 56.55 & 54.53 & 105.56 & 75.34 & 21.72 & 19.49 & 18.72 & 9.09 \\
\hline Sakha 106 & 96.95 & 76.75 & 4.04 & 7.07 & 57.56 & 50.50 & 109.49 & 81.96 & 20.50 & 19.29 & 19.09 & 11.11 \\
\hline Sakha 107 & 92.63 & 80.66 & 3.99 & 4.98 & 52.78 & 46.80 & 110.95 & 79.67 & 18.72 & 16.33 & 20.79 & 15.94 \\
\hline WAB 56-50/Sakha 101-1 & 98.59 & 84.65 & 2.00 & 4.98 & 57.76 & 59.75 & 107.35 & 71.90 & 19.22 & 18.53 & 19.92 & 13.94 \\
\hline WAB 56-50/Sakha 101-2 & 107.49 & 89.63 & 2.00 & 3.99 & 51.79 & 63.73 & 107.05 & 77.08 & 24.90 & 16.93 & 19.72 & 14.14 \\
\hline IR 65907-206-7-8/ Gyehwa71 & 99.95 & 85.64 & 2.99 & 2.99 & 21.91 & 19.92 & 114.52 & 69.31 & 18.23 & 17.23 & 19.22 & 13.94 \\
\hline LSD 0.05 & \multicolumn{2}{|c|}{2.11} & \multicolumn{2}{|c|}{0.09} & \multicolumn{2}{|c|}{1.07} & \multicolumn{2}{|c|}{1.91} & \multicolumn{2}{|c|}{0.41} & \multicolumn{2}{|c|}{0.33} \\
\hline LSD 0.01 & \multicolumn{2}{|c|}{2.99} & \multicolumn{2}{|c|}{0.13} & \multicolumn{2}{|c|}{1.51} & \multicolumn{2}{|c|}{2.70} & \multicolumn{2}{|c|}{0.59} & \multicolumn{2}{|c|}{0.47} \\
\hline
\end{tabular}

Table 6. Cont'd

\begin{tabular}{|c|c|c|c|c|c|c|c|c|c|c|}
\hline \multirow[t]{2}{*}{ Genotype } & \multicolumn{2}{|c|}{$\begin{array}{c}\text { Number of } \\
\text { Panicles/plant }\end{array}$} & \multicolumn{2}{|c|}{$\begin{array}{c}\text { Panicle weight } \\
\text { (g) }\end{array}$} & \multicolumn{2}{|c|}{$\begin{array}{c}\text { 100-Grain weight } \\
\text { (g) }\end{array}$} & \multicolumn{2}{|c|}{$\begin{array}{c}\text { Sterility } \\
\text { Percentage }(\%)\end{array}$} & \multicolumn{2}{|c|}{$\begin{array}{c}\text { Grain yield/plant } \\
\text { (g) }\end{array}$} \\
\hline & $\mathbf{N}$ & $\mathbf{H}$ & $\mathbf{N}$ & $\mathbf{H}$ & $\mathbf{N}$ & $\mathbf{H}$ & $\mathbf{N}$ & $\mathbf{H}$ & $\mathbf{N}$ & $\mathbf{H}$ \\
\hline Giza 177 & 18.69 & 8.08 & 4.01 & 1.17 & 2.79 & 2.34 & 5.36 & 51.22 & 43.54 & 10.91 \\
\hline Giza 178 & 19.92 & 13.14 & 4.88 & 1.39 & 2.38 & 2.11 & 5.34 & 23.88 & 51.02 & 22.13 \\
\hline Giza179 & 17.58 & 15.16 & 3.70 & 1.28 & 2.80 & 2.12 & 6.06 & 39.01 & 51.72 & 26.06 \\
\hline Sakha 101 & 17.99 & 9.09 & 3.78 & 1.18 & 3.25 & 2.56 & 6.47 & 40.61 & 49.50 & 20.20 \\
\hline Sakha 102 & 19.49 & 11.11 & 3.73 & 0.77 & 2.88 & 2.28 & 4.86 & 70.47 & 44.42 & 11.11 \\
\hline Sakha 103 & 20.00 & 7.07 & 4.33 & 0.57 & 2.53 & 1.76 & 4.52 & 74.12 & 43.60 & 11.31 \\
\hline Sakha 104 & 16.46 & 12.12 & 4.28 & 1.14 & 3.22 & 2.57 & 5.70 & 30.42 & 48.18 & 18.18 \\
\hline Sakha 105 & 17.67 & 9.09 & 3.86 & 0.71 & 3.19 & 2.24 & 6.93 & 63.62 & 43.22 & 15.25 \\
\hline Sakha 106 & 19.19 & 10.10 & 3.92 & 0.55 & 2.93 & 2.14 & 5.45 & 45.81 & 43.73 & 16.26 \\
\hline Sakha 107 & 20.71 & 14.94 & 3.88 & 1.54 & 2.73 & 2.22 & 4.49 & 34.16 & 44.22 & 23.90 \\
\hline WAB 56-50/Sakha 101-1 & 19.59 & 13.15 & 3.00 & 1.68 & 3.15 & 2.39 & 5.58 & 26.09 & 24.11 & 24.76 \\
\hline WAB 56-50/Sakha 101-2 & 18.99 & 12.15 & 4.82 & 1.79 & 2.20 & 2.19 & 6.97 & 22.55 & 25.20 & 25.93 \\
\hline IR65907-206-7-8/ Gyehwa71 & 18.72 & 13.94 & 4.64 & 1.09 & 2.88 & 2.37 & 8.07 & 15.55 & 24.88 & 25.65 \\
\hline LSD 0.05 & \multicolumn{2}{|c|}{0.34} & \multicolumn{2}{|c|}{0.06} & \multicolumn{2}{|c|}{0.04} & \multicolumn{2}{|c|}{0.74} & \multicolumn{2}{|c|}{0.71} \\
\hline LSD 0.01 & \multicolumn{2}{|c|}{0.48} & \multicolumn{2}{|c|}{0.08} & \multicolumn{2}{|c|}{0.06} & \multicolumn{2}{|c|}{1.05} & \multicolumn{2}{|c|}{1.00} \\
\hline
\end{tabular}




\section{Genetic variability}

Genotypic variance $(\mathrm{GV})$, phenotypic variance $(\mathrm{PV})$, genotypic coefficient of variability (GCV), phenotypic coefficient of variability (PCV), broad-sense heritability $\left(\mathrm{H}^{2}\right)$ and genetic advance (GA) for 13 characters are presented in Table (7). To determine the variation in yield components responsible for differences in yield among various genotypes, it must be borne in mind that overall variability depends on heritable and nonheritable components. While coefficients of variation measure the magnitude of variability present in a population, estimates of heritability and genetic advances are important as preliminary steps in any breeding program as they provide information needed in designing the most effective breeding program and the relative practicability of selection. The results revealed considerable phenotypic and genotypic variances among the genotypes for the traits under consideration. In all traits a large portion of the phenotypic variance was accounted by the genetic component and the contributions of genetic variance to phenotypic variance. Generally, the PCV values were higher than GCV values for all studied traits, which reflect the influence of environment on the expression of these traits. Plant height was the most trait affected by the environment than the genotype variation, where the estimated PCV was 9.15 in compared with 8.90 for GCV. The estimates of GCV were high for all studied traits ranging between 21.09 - $95.54 \%$ characters except days to heading, plant height and panicles length, the three traits were recorded moderate GCV estimates, in range 8.90 - $19.99 \%$. These findings seem to comply with Andrew et al. 2016, who stated that, different rice genotypes showed different levels of tolerance to high day temperatures, consistent with the climatic characteristics of their natural ranges.

Higher heritability estimates for days to heading, Flag leaf angle, sterility percentage and grain yield/plant combined with high genetic advance, indicating the presence of additive genes. The expected genetic advance values for 13 characters of the genotypes evaluated is presented in Table (7). These values are also expressed as percentage of the genotypes mean for each character so that comparison could be made among various characters, which had different units of measurement. High heritability along with high genetic advance is an important factor for predicting the resultant effect for selecting the best individuals. The genotypic coefficient of variation revealed the extent of genetic variability present in the genotypes for various traits it does not provide full scope to assess the variation that is heritable. Heritable variation is useful for permanent genetic improvement (Singh 2000). The most important function of the heritability in the genetic study of quantitative characters is its predictive role to indicate the reliability of the phenotypic value as a guide to breeding value.

Table 7. Genetic parameters for studied traits under 2017 and 2018 rice growing seasons.

\begin{tabular}{|c|c|c|c|c|c|c|c|c|c|c|c|c|}
\hline & \multicolumn{2}{|c|}{$\begin{array}{c}\text { Days to } \\
\text { heading(day) }\end{array}$} & \multicolumn{2}{|c|}{ Leaf rolling } & \multicolumn{2}{|c|}{ Flag leaf angle $\left(^{\circ}\right)$} & \multicolumn{2}{|c|}{$\begin{array}{l}\text { Plant height } \\
\text { (cm) }\end{array}$} & \multicolumn{2}{|c|}{$\begin{array}{c}\text { Panicles length } \\
(\mathrm{cm})\end{array}$} & \multicolumn{2}{|c|}{$\begin{array}{l}\text { Number of } \\
\text { tiller/plant }\end{array}$} \\
\hline & 2017 & 2018 & 2017 & 2018 & 2017 & 2018 & 2017 & 2018 & 2017 & 2018 & 2017 & 2018 \\
\hline GV & 203.11 & 205.97 & 8.51 & 8.65 & $1,492.02$ & $1,512.95$ & 69.56 & 70.54 & 9.66 & 9.78 & 11.30 & 11.47 \\
\hline $\mathrm{Pv}$ & 208.01 & 210.95 & & 8.66 & $1,493.26$ & $1,514.21$ & 73.58 & 74.62 & 84 & 9.9 & 11.42 & 11.59 \\
\hline GCV & 15.61 & 15.61 & 68.90 & 69.00 & & 81.73 & 8.90 & 8.90 & 16.01 & 16.00 & 21.09 & 21.10 \\
\hline PCV & 15.79 & 15.79 & 68.94 & 69.04 & 81.76 & 81.76 & 9.15 & 9.15 & 16.16 & 16.16 & 21.20 & 21.21 \\
\hline $\mathrm{H}^{2}$ & 97.64 & 97.64 & 99.88 & 99.88 & 99.92 & 99.92 & 94.54 & 94.54 & 98.17 & 98.00 & 98.95 & 98.96 \\
\hline GA & 29.01 & 29.21 & 6.00 & 6.05 & 79.54 & 80.09 & 16.71 & 16.82 & 6.34 & 6.38 & 6.89 & 6.94 \\
\hline
\end{tabular}

Table 7. Cont'd

\begin{tabular}{lcccccccccc}
\hline & $\begin{array}{c}\text { Number of } \\
\text { panicles/plant }\end{array}$ & \multicolumn{2}{c}{$\begin{array}{c}\text { Panicle weight } \\
(\mathbf{g})\end{array}$} & \multicolumn{2}{c}{$\begin{array}{c}\text { 100-Grain } \\
\text { weight }(\mathbf{g})\end{array}$} & \multicolumn{2}{c}{$\begin{array}{c}\text { Sterility } \\
\text { Percentage (\%) }\end{array}$} & \multicolumn{2}{c}{$\begin{array}{c}\text { Grain yield/plant } \\
\text { (g) }\end{array}$} \\
\cline { 2 - 11 } & $\mathbf{2 0 1 7}$ & $\mathbf{2 0 1 8}$ & $\mathbf{2 0 1 7}$ & $\mathbf{2 0 1 8}$ & $\mathbf{2 0 1 7}$ & $\mathbf{2 0 1 8}$ & $\mathbf{2 0 1 7}$ & $\mathbf{2 0 1 8}$ & $\mathbf{2 0 1 7}$ & $\mathbf{2 0 1 8}$ \\
\cline { 2 - 10 } & 12.87 & 13.05 & 0.66 & 0.68 & 0.36 & 0.36 & 504.21 & 511.33 & 130.67 & 132.47 \\
$\mathrm{GV}$ & 12.99 & 13.17 & 0.66 & 0.68 & 0.36 & 0.36 & 504.81 & 511.93 & 131.21 & 133.03 \\
$\mathrm{PV}$ & 23.75 & 23.75 & 31.32 & 31.56 & 23.62 & 23.45 & 95.54 & 95.54 & 37.80 & 37.80 \\
$\mathrm{GCV}$ & 23.86 & 23.86 & 31.42 & 31.66 & 23.68 & 23.52 & 95.59 & 95.60 & 37.88 & 37.88 \\
$\mathrm{PCV}$ & 99.03 & 99.09 & 99.40 & 99.41 & 99.45 & 99.45 & 99.88 & 99.88 & 99.59 & 99.58 \\
$\mathrm{H}^{2}$ & 7.35 & 7.41 & 1.67 & 1.69 & 1.23 & 1.23 & 46.23 & 46.55 & 23.50 & 23.66 \\
$\mathrm{GA}$ & & & & & & & & & & \\
\hline
\end{tabular}


Table 7. Cont'd

\begin{tabular}{lcccccc}
\hline & \multicolumn{2}{c}{ The geometric mean (GM) } & \multicolumn{2}{c}{ Stress susceptibility index } & \multicolumn{2}{c}{ Yield index, } \\
\cline { 2 - 7 } & $\mathbf{2 0 1 7}$ & $\mathbf{2 0 1 8}$ & $\mathbf{2 0 1 7}$ & $\mathbf{2 0 1 8}$ & $\mathbf{2 0 1 7}$ & $\mathbf{2 0 1 8}$ \\
\cline { 2 - 7 } GV & 49.76 & 57.23 & 1.20 & 1.20 & 0.24 & 0.24 \\
PV & 53.56 & 60.00 & 1.42 & 1.21 & 0.25 & 0.25 \\
GCV & 26.30 & 27.78 & 90.80 & 96.26 & 46.07 & 45.30 \\
PCV & 27.29 & 28.45 & 98.85 & 96.62 & 46.94 & 46.29 \\
H & 92.92 & 95.38 & 84.38 & 99.26 & 96.34 & 95.78 \\
GA & 14.01 & 15.22 & 2.07 & 2.25 & 0.99 & 0.98 \\
\hline
\end{tabular}

The genotypic coefficient of variation along with heritability estimates provide reliable estimates of the amount of genetic advance to be expected through phenotypic selection. The results were also reported by Gaballah 2009, who supported the present findings. Heritability and genetic advance are important selection parameters. The estimates of genetic advance help in understanding the type of gene action involved in the expression of various polygenic characters. High values of genetic advance are indicative of additive gene action, whereas low values are indicative of nonadditive gene action (Singh and Narayanan 1993). Thus the heritability estimates will be reliable if accompanied by high genetic advance.

\section{Phenotypic correlations among characters:}

Data in Table 8 revealed the phenotypic correlation coefficients among grain yield and phenological and physiological characters related to heat tolerance. The phenotypic correlation is the correlation of line means for different traits, or for the same trait in different environments. The phenotypic correlations estimated for agronomic traits are presented in Table (8). Days to heading showed highly significant positive correlation with plant height, tillers No. and panicle weight, and negative correlation with leaf rolling, sterility \%, geometric mean and yield index. Leaf rolling exhibited highly significant positive phenotypic correlation with leaf angle, sterility \%, geometric mean and yield index while had negative phenotypic correlation with tillers No., panicle No. and panicle weight in both seasons. Being a leaf rolling as a canopy cooling mechanism and reducing water losses through transpiration, is significantly correlated negatively with most of yield components and positively correlated with sterility $\%$ in a high score $0.83^{* *}$, that reflects its importance as one of the earlier criterion to predict grain yield. These results seem to indicate that heat susceptibility of the rice is highly correlated with high score of leaf rolling (O`toole and Moya 1978). Leaf angle showed highly significant positive phenotypic correlation with leaf rolling and sterility \%, and negative significant correlated with panicle No., panicle weight and grain yield. The morphological trait, i.e. leaf angle ranked second after yield components in their positive associations with grain yield. The degree of the phenotypic correlations and its utilization in the selection had been stated by Gaballah 2009. The negative phenotypic correlations were found to be highly significant with panicle length and geometric mean in both seasons.

Data in Table 8 showed that the tillers No. had significant positive correlation with panicle No. and panicle weight, while correlated negatively with sterility $\%$, geometric mean and yield index. Moreover, the panicles No., which is the main component of grain yield, gave the highest positive and significant phenotypic correlation $(0.87 * *)$ with tillers No., that might refer to the importance of tillering capacity in implying that improving this character could result in high grain yield, as tillers have the potential to develop ear bearing tillers. Significant positive phenotypic correlation was found between panicle No. and panicle weight, but negative significant correlation was shown between panicle No. and sterility $\%$ and yield index. Panicle weight had highly significant negative correlation with 100-grain weight, sterility $\%$, stress susceptibility index and yield index, but 100-grain weight was highly significantly correlated positively with stress susceptibility index. These findings agree with Ramchander et al. 2014. Highly positive and significant phenotypic correlations existed between yield index and leaf rolling, Sterility \%, geometric mean and stress susceptibility index, that proved to be the most useful indices for the evaluation of genotypic performance under heat stress and they were highly correlated (Table 8), as expected, due to their united direction against heat stress. In other words, all these traits were negatively affected by heat stress. In contrast, the most important traits (tillers No., panicle No. and panicle weight), as yield components had negatively correlation with yield index. That also might reflect how importance of these indices to express genotypes response under stress codition. 
Table 8. Phenotypic correlation among studied traits under heat stress and normal conditions in 2017 and 2018 growing seasons

\begin{tabular}{|c|c|c|c|c|c|c|c|c|c|c|c|c|c|}
\hline Traits & DTH & LR & FLA & PH & PL & NT & NP & PW & HGW & SP & GYP & GM & SSI \\
\hline LR & $-0.65^{* *}$ & & & & & & & & & & & & \\
\hline FLA & -0.04 & $0.61^{* *}$ & & & & & & & & & & & \\
\hline $\mathrm{PH}$ & 0.12 & 0.23 & 0.16 & & & & & & & & & & \\
\hline PL & $0.37 * *$ & 0.04 & 0.22 & 0.29 & & & & & & & & & \\
\hline NT & $0.40 * *$ & $-0.66^{* *}$ & -0.25 & 0.14 & -0.04 & & & & & & & & \\
\hline $\mathrm{NP}$ & 0.02 & $-0.60 * *$ & $-0.50^{* *}$ & -0.02 & -0.25 & $0.87 * *$ & & & & & & & \\
\hline PW & $0.61 * *$ & $-0.72 * *$ & $-0.38^{* *}$ & -0.02 & 0.08 & $0.46^{* *}$ & $0.38^{* *}$ & & & & & & \\
\hline HGW & 0.21 & 0.13 & 0.27 & 0.01 & -0.12 & -0.02 & -0.23 & $-0.45^{* *}$ & & & & & \\
\hline $\mathrm{SP}$ & $-0.62^{* *}$ & $0.86 * *$ & $0.43^{* *}$ & 0.20 & 0.19 & $-0.68^{* *}$ & $-0.61^{* *}$ & $-0.67^{* *}$ & -0.08 & & & & \\
\hline GYP & 0.20 & -0.25 & $-0.42^{* *}$ & 0.22 & 0.11 & 0.27 & 0.19 & 0.06 & 0.04 & -0.11 & & & \\
\hline GM & $-0.46^{* *}$ & $0.37 * *$ & 0.16 & -0.001 & $-0.62 * *$ & $-0.31 *$ & -0.19 & -0.02 & -0.29 & $0.33 * *$ & -0.06 & & \\
\hline SSI & -0.06 & $0.32 *$ & 0.06 & -0.08 & 0.05 & -0.19 & -0.28 & $-0.34^{*}$ & $0.40 * *$ & 0.13 & -0.11 & -0.19 & \\
\hline YI & $-0.43^{* *}$ & $0.67 * *$ & 0.25 & 0.08 & -0.22 & $-0.40 * *$ & $-0.41^{* *}$ & $-0.43^{* *}$ & 0.18 & $0.51^{* *}$ & -0.18 & $0.40 * *$ & $0.78 * *$ \\
\hline
\end{tabular}

(NS) = Not Significant, $(*)=$ Significant at 0.05 and $(* *)=$ Significant at 0.01 level of probability.

DTH = Days to heading, $\mathrm{LR}=$ Leaf rolling, FLA= Flag leaf angle, $\mathrm{PH}=$ Plant height, $\mathrm{PL}=$ Panicle length, NT=number of tillers/plant, $\mathrm{NP}=$ number of panicles/plant, $\mathrm{PW}=$ Panicle weight, $\mathrm{HGW}=100$-grain weight, $\mathrm{SP}=$ Sterility percentage, $\mathrm{GYP}=$ Grain yield/plant, GM= Geometric mean, SST= Stress susceptibility Index, YI =Yield index.

The results regarding this investigation is supported by those revealed by Chang and Loresto 1984, both suggested that, the genotypes can be scored as stress tolerant, based on days to heading, leaf rolling and drying and spikelets sterility percentage.

\section{REFERENCES}

Abdallah, A. A. 2015. Development of High Yielding Rice Lines Tolerant to Drought and Heat Stress Conditions in Egypt. World Rural Observations.7(1):58-64

Akhtar, N., M. F. Nazir, A. Rabnawaz, T. Mahmood, M. E.Safdar, M. Asif and A. Rehman.2011. Estimationof heritability, correlation and path coefficient analysis in fine grain rice (Oryza sativa L.) The J.Anim. Plant Sci. 21(4): 660-664.

Andrew, P. S., G. Alexander, V. R. Jeroen, C. S. Elizabete, E. S. Michael and J. A. Brian. 2016. Heat tolerance in a wild Oryza species is attributed to maintenance of Rubisco activation by a thermally stable Rubisco activase ortholog, New Phytologist (2016) 211: 899911. doi: 10.1111/nph.13963

Ayeneha, A., M van Ginkelb, M. P. Reynoldsb and K. Ammarb.2002.Comparison of leaf, spike, peduncle and canopy temperature depression in wheat under heat stress, Field Crops Research, 69(2-3): 173-184

Chang, T. T., and G. C. Loresto. 1984. Screening techniques for drought resistance in rice. Paper presented in national seminar on Breeding for Stress Resistance in Crop Plants, 12-13 at 1984, Haryana Agricultural University, Hissar; India. 29 p. (unpubl.)
Comstock, R. R. and H. F. Robinson. 1952.Genetic parameters, their estimation and significance, Proc. 6TH international Grassland Congress. Vol. 1, Nat. publ. Co. Wash., D.C., U.S.A., pp: 248-291.

Crafts-Brandner S. J. and R. D. Law. 2000. Effect of heat stress on the inhibition and the recovery of the ribulose1,5-bisphosphate carboxylase/oxygenase activation state. Planta 212:67-74

Falconer, D. S. and T. F. C. Mackay.1996. Introduction to Quantitative Genetics, Ed4. Longmans Green, Harlow, Essex, UK.

FAOSTAT.2016.Statistical data base. Food and Agriculture Organizations of the United Nations. Rome, Italia. http://www.fao.org/faostat/en/\#data

Farrell, T. C., K. M. Fox, R. L. Williams and S. Fukai. 2006.Genotypic variation for cold tolerance during reproductive development in rice: screening with cold air and cold water. Field Crops Research 98: 178-194.

Fischer, R. A. and R. Maurer.1978.Drought resistance in spring wheat cultivars. I. Grain yield responses. Aust J Agric Res 29:892-912.

Gaballah, M. M. 2009. Studies on physiological and morphological traits associated with drought resistance in rice (Oryza sativa L.).PhD thesis, Kafer El-Sheikh University.

Gaballah, M .M. 2016. Genetic variation, heritability, phenotypic and genotypic correlation studies for yield and yield components of rice genotypes. Egypt. J. Plant Breed. 20(1):75 - 89 . 
Gavuzzi, P., F. Rizza, M. Palumbo, R. G. Campaline, G. L. Ricciardi and B. Borghi. 1997. Evaluation of field and laboratory predictors of drought and heat tolerance in winter cereals. Can J Plant Sci 77: 523-531.

Griffin, J. J., T. G. Ranney and D. M. Pharr. 2004.Heat and drought influence photosynthesis and water relations, and soluble carbohydrates of two ecotypes of redbud (Cercis canadensis). J Am Soc Hortic Sci 129:497-502.

Guan, Y. S., R. Serraj, S. H. Liu, J. L. Xu, J. Ali, W.S. Wang, E. Venus, L.H. Zhu and Z .K. Li. 2010. Simultaneously improving yield under drought stress and nonstress conditions: A case study of rice (Oryza sativa L.). J. Exper. Botany 61(15): 4145-4156.

Han, F., H. Chen and X. J. Li. 2009. A comparative proteomic analysis of rice seedlings under various high-temperature stresses, Biochim Biophys Acta, 1794: 1625-1634

IPCC. 2007. Climate change 2007: Impacts, Adaptation and Vulnerability, Contribution of Working Group II, the Fourth Assessment Report of the Intergovernmental Panel on Climate Change, M.L. Parry, O.F. Canziani, J.P. Palutikof, P.J. van der Linden and C.E. Hanson, Eds., Cambridge University Press, Cambridge, UK, 976pp.

IRRI.1976. Annual Report. Manila, The Philippines: IRRI.

Jagadish, S. V. K., P. Q. Craufurd and T. R. Wheeler.2007. High temperature stress and spikelet fertility in rice (Oryza sativa L.). J Exp Bot 58:1627-1635

Jones, P. D., M. New, D. E. Parker, S. Martin and I. G. Rigor .1999. Surface air temperature and its changes over the past 150 years, reviews of geophysics.37. 2: 1 73-199.

Khan, I. M. and O. P. Dhurve.2016. Drought response indices for identification of drought tolerant genotypes in rainfed upland rice (oryza sativa 1.). International journal of science, environment and technology. 5(1): $73-83$.

Kown, S. H. and J. H. Torrie.1964. Heritability and interrelationship among traits of two soybean populations. J. Crop Sci. 4: 196-198.

Matsui, T, K. Omasa and T. Horie.2001. The difference in sterility due to high temperatures during the flowering period among japonica rice varieties. Plant Prod Sci 4:9093.

Mohammed, A. R. and L. Tarpley.2009. High night temperatures affect rice productivity through altered pollen germination and spikelet fertility. Agric. For. Meterol. 149: 9 99_1008.

Mohammed, A. R. and L. Tarpley.2010.High night temperature and plant growth regulator effects on spikelet sterility, grain characteristics and yield of rice (Oryza sativa L.) plants, Can. J. Plant Sci. (2011) 91: 283-291

Nagarajan, S, S. V. K. Jagadish and A. S. H. Prasad.2010. Local climate effects growth, yield and grain quality of aromatic and non-aromatic rice in north western India. Agric Ecosyst Environ138:274-281.
Nakagawa, H., W. Takahashi, T. Hasegawa, T. Watanabe, and T. Horie.2001. Development of a three-dimensional simulator for rice growth and development. II. Accuracy of a rice phenology model to simulate heading stage and plant age in leaf number. Japanese Journal of Crop Science 70:125-126.

Nakagawa, H, T. Horie and T. Matsui.2002. Effects of climate change on rice production and adaptive technologies. In: Mew TW, Brar DS, Peng S, Dawe D, Hardy B (eds) Rice science: innovations and impact for livelihood. International Rice Research Institute, China, pp 635-657

Ohe, I., K. Saitoh and T. Kuroda.2007. Effects of high temperature on growth, yield and dry-matter production of rice grown in the paddy field. Plant Prod Sci 10:412-422

O'Toole, J. C., and T. B. Moya.1978.Genotypic variation in maintenance of leaf water potential in rice. Crop Sci. 18:873-876.

Peng, S. B., J. L. Huang and J. E. Sheehy.2004. Rice yields decline with higher night temperature from global warming. Proc Natl Acad Sci USA 101:9971-9975.

Poehlman, J.M. and D.A. Sleper.1995.Breeding Field Crops. Iowa State Press, Ames, Iowa, USA.

Porter, J. R. and D. J. Moot .1998. Research beyond the means: climatic variability and plant growth. In: Dalezios NR (ed) International symposium on applied agrometeorology and agroclimatology. Office for Official Publication of the European Commission, Luxembourg, pp 13-23

Prasad, P. V. V., K. J. Boote, L. H. Allen .2006. Species, ecotype and cultivar differences in spikelet fertility and harvest index of rice in response to high temperature stress. Field Crops Res 95:398-411.

Prasanth, V. V., D. V. N. Chakravarthi, T. Vishnu Kiran, Y. Venkateswara Rao,Madhusmita Panigrahy, S. K. Mangrauthia, B. C. Viraktamath, D. Subrahmanyam and S. R. Voleti.2012. Evaluation of rice germplasm and introgression lines for heat tolerance. Annals of Biological Research, 3 (11):5060-5068.

Ramchander, S., S. Robini and M. Raveendran.2014.Correlation Analysis for PhysioMorphological Traits of Drought Resistance in Advanced Backcross Population of Rice (Oryza sativa L.), Trends in Biosciences 7(16): 2117-2122.

Ramirez Vallejo, P. and J. D. Kelly .1998. Traits related to drought resistance in common bean. Euphytica 99:127136.

Rampino, P, S. Pataleo and C. Gererdi .2006.Drought response in wheat: physiological and molecular analysis of resistant and sensitive genotypes. Plant Cell Environ 29:2143-2152.

Satak, T. and S. Yoshida .1978. High temperature-induced sterility in indica rices at flowering. Japanese Journal of Crop Science 47:6-17. 
Schwarz, D., Y. Rouphael, G. Colla and H. J. Venema.2010.Grafting as a tool to improve tolerance of vegetables to abiotic stresses:Thermal stress, water stress and organic pollutants, Scientia Horticulturae, 127: 162171.

Shah, F., J. Huang, K. Cui, L. Nie, T. Shah, C. Chen and K. Wang.2011. Impact of high-temperature stress on rice plant and its traits related to tolerance. Journal of Agricultural Science, Page 1 of 12.

Singh, B. D. 2000. Plant Breeding: Principles and Methods. Kalyani Publishers, New Delhi.

Singh, P. and S. S. Narayanan.1993. Biometrical Techniques in Plant Breeding, first ed. Kalyani Publishers, New Delhi, India.

Steel, R. D. G., J. H. Torrie, and D. A. Dickey.1997.Principles and Procedures of Statistics: A biometrical approach (3 rd Ed). McGraw Hill Book Co., New York. Pp. 400-408

Stone, P. 2001. The effects of heat stress on cereal yield and quality. In: Basra, A. S. (Ed.) Crop Responses and Adaptations to Temperature Stress. (Binghamton, New York, Food Products Press). p: 243-29.
Wahid, A., Gelani, S.; M. Ashraf and M. R. Foolad .2007. Heat tolerance in plants: An overview, Environmental and Experimental Botany.6: 199- 223.

Wang, W., B. Vinocur and A. Altman.2003.Plant responses to drought, salinity and extreme temperatures: towards genetic engineering for stress tolerance. Planta.218: 1-14.

Yin, X., M. J. Kroff, and J. Goudriaaa.1996. Differential effects of day and night temperature on development to flowering in rice. Annals of Botany 77:203-213.

Yoshida, S. (1981). Fundamentals of Rice Crop Science. Los Baños, The Philippines: IRRI

Yoshida, S, T. Satake and D. S. Mackill.1981.High temperature stress in rice, IRRI Research Paper Series, Vol. 67.

Zhao C., B. L., P. Shilong, X. Wang, David B. Lobell, Y. Huang, M. Huang, Y. Yao. 2017.Temperature increase reduces global yields of major crops in four independent estimates, PNAS, 114(35) 9326:933. 


\section{الملخص العربي}

\section{السلوك الور اثي لبعض التراكيب الوراثية للأزز تحت الظروف الطبيعية والاجهاد الحرارى}

محمود محمد محمود جاب الله، عزيز فؤاد السيد ابو العز

الاخرب في صفة محصول الحبوب ومكوناتة بينما أعطت

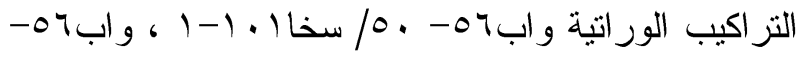

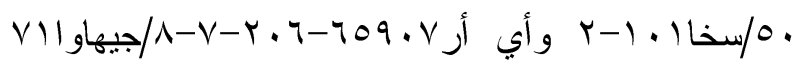
أدنى محصول حبوب في كلا موسمين الزراعة. سجل

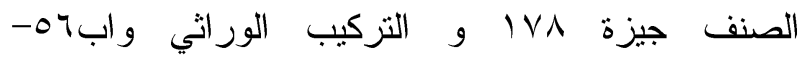
• •/سخا 1.1-1 اقل القيم للاليل الحسابي لمتوسط الانتاجية ودليل الحساسية للاجهاد ودليل المحصول مما يعكس درجة عالية لهذه التراكيب الور اثية لتحمل الاجهاد

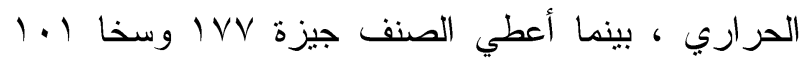
أعلى القيم لتكون الأكثر حساسية للاجهاد الحرارى تحت لبت الدراسة. وجد ارتباط عالي المعنوية وموجب بين دليل المحصول ودرجة التفاف الأوراق ، ونسبة العق ، و الدليل

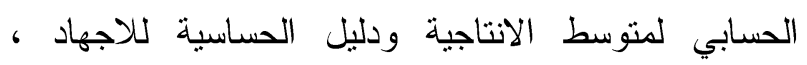
وبالاتجاه الاخر ارتبطت صفات مكونات المحصول صفة وديه عدد الفروع / نبات ، وعدد السنابل/ نبات ووزن السنبلة ارتباطا سالبا وعالي المعنويه بدليل المحصول. من النتائج

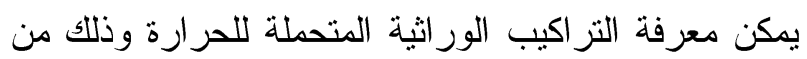
خلال صفة عدد الايام حتي التزهير، ودرجة التفاف الأوراق ، و عدد الفروع /نبات ونسبة السنيبلات العقيمة.
اجريت تجربتان حقليتان تحت الظروف الطبيعية

لمحصول الارز بمحطة البحوث الزراعية بسخا - بكفر

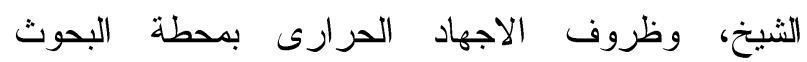
الزر اعية في الخارجة - بمحافظة الو ادى الجديد لتقييم ثلاثة

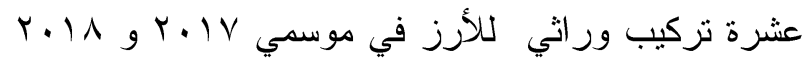
لدر اسة مدى التباين في الصفات المرغوبة وتقدير القياسات الور اثية ومعامل الارتباط للصفات المختلفة تحت الظروف مدى الطبيعية والإجهاد الحراري. اظهر تحليل التباين اختلافات عالية المعنوية للظروف البيئة و التز اكيب الور اثية و التفاعل بينهما لكل الصفات المدروسة في كلا موسمين الزراعة. كانت تقدير ات معامل التغير الور اثي (GCV) ومعامل التغير

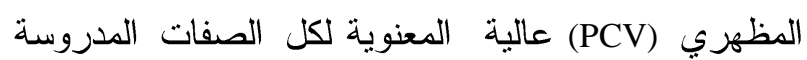
و عموما كانت قيم معامل التغير المظهري PCV أعلى من قيم معامل التغير الوراثي (GCV) في كلا موسمين

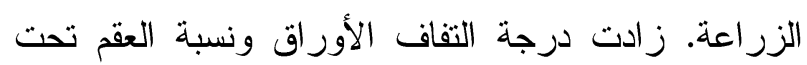
الاجهاد الحراري ، بينما قل عدد الأيام حتي التزهير، طول

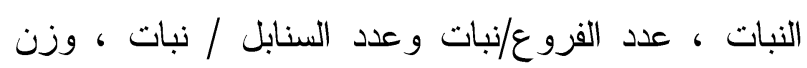
. . . حبة و محصول الحبوب / نبات تحت الاجهاد الحراري بالمقارنة بالظروف الطبيعية. تفوق الصنف جيزة

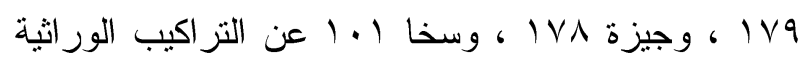

